\section{PRIZES OFFERED BY THE SOCIETTÉ D'ENCOURAGEMENT}

THE Bulletin of the Société d'Encouragement pour l'Industrie Nationale contains a list of the medals and prizes to be awarded in 1897 and 1898 . Amongst these, the following prizes are proposed for 1897 . In the Mechanical Arts : for improved methods in milling of grain (2000 francs); for a motor weighing less than 50 kilogrammes per horse-power developed for use in aërial navigation (2000 francs); for a study of the coefficients necessary for the calculations of an aerial machine (2000 francs); for a small motor suitable for domestic use (2000 francs); for improvements in machine tools (2000 francs).

In the Chemical Arts : for the utilisation of waste products (I000 francs); for a new method of preparing fuming sulphuric acid or sulphur trioxide, which shall be more economical than those at present in use (2000 francs); for a liquid which shall replace sulphuric acid in dyeing, especially of silk, without exercising the same destructive action on the fibre ( 1000 francs); for a scientific study of the physical and mechanical properties of glass ( 2000 francs); for the preparation on the large scale of a new alloy of iron possessing specially useful properties (2000 francs).

In the Economic Arts : prizes are offered for the construction of a hydro-extractor that can be worked continuously (2000 francs), and for important improvements in the manufacture of permanent magnets, with especial reference to their stability (3000 francs).

In Agriculture : for a study of alcoholic ferments (3000 francs); for the best study of the diseases of cider and the means of arresting their development (2000 francs); for the best practical means of destroying one of the insect enemies of the vine (1000 francs). There will also be awarded in 1897 a prize of 2000 francs for an economic study of an industrial centre in France, and of 1500 francs for a study of insurance against involuntary want of employment.

The more important prizes offered for 1898 include the Marquis d'Argenteuil prize of 12,000 francs for the discovery of the greatest service in developing French industry ; for a publication of service to chemical or metallurgical industry (2000 francs); for an experimental study of the physical or mechanical properties of some metal or alloy in common use ( 2000 francs); for the invention of new methods of utilising petroleum (o $8 \mathrm{k}$. or higher) advantageously and without danger, for either manufacturing or domestic purposes (2000 francs); for the best varieties of barley for brewing (1500 francs); for the reconstitution of vineyards upon chalky soils (30ó francs); and for the best study in vine culture in France ( 2000 francs).

\section{SCIENCE IN THE MAGAZINES.}

GLACIALISTS making arrangements for their summer migration to Switzerland, and other geologists interested in ice-work, should read what Dr. A. R. Wallace has to say in the Fortnightly on "The Gorge of the Aar and its Teachings," before they set out, and they will then be able to judge for themselves the weight of the conclusions drawn. Dr. Wallace thinks the phenomena presented by the valley of the Aar afford " a fresh and very powerful argument in support of the power of the ancient glaciers both to deepen valleys and to grind out lakebasins," and his article is written to prove the correctness of this view. In the enclosed valley with its two small rockbasins in which the Hospice in the Grimsel Pass is situated, Dr. Wallace sees an example of the effects of a kind of eddy in old ice-streams flowing in nearly opposite directions. The celebrated Aarschlucht, one of the most remarkable gorges in Europe, is from 200 to 300 feet deep, and only about six feet in width. This is held to represent " the result of the action of sub-glacial torrents acting throughout the whole period during which the area was buried in ice. Thus only are we able to explain the fact of the almost uniform narrowness of the gorge from bottom to top, since during the process of its formation the rock walls would be preserved from ordinary denuding agencies, and be kept at a nearly uniform temperature." This view of the origin of the gorge is held by Prof. Bonney and by other geologists who have considered the subject, though the conclusions to which it leads differ. A number of other gorges in Switzerland are similarly explained. Accepting this interpretation, it is evident that gorges of this character ought only to be found in regions which have been recently glaciated. "In our own country," says Dr. Wallace, "we have many small gorges of this character, in Wales, the Lake District, and Scotland, that of Dungeon Gill, in Westmoreland, being an example; but more are to be found in decidedly non-glaciated areas, such as Devonshire, though narrow ravines are common enough. So in the Northern United States there are many such gorges, the Ausible Chasm in the Adirondacks, and Watkin GIen, near Seneca Lake, are well-known tourist resorts; but in the Southern States, beyond the glaciated area, there are no similar gorges, although the southern Alleghenies are loftier than farther north, and contain much grand and picturesque mountain scenery and many waterfalls and deep ravines, but these are all of the rugged and weathered type." In the mountainous region of Brazil, where there has certainly been no recent glaciation, Prof. Branner testifies that none of the characteristic sub-glacial stream channels occur. Finally, the gorges of the Aar, and others of like nature, are shown to afford evidence in favour of the theory of the glacial origin of the Swiss valley lakes. The abrupt Kirchet Hill, which extends across the valley of the Aar, is adduced by Prof. Bonney as an argument against this theory. "This would be a valid objection," says Dr. Wallace, "if the Aar glacier had continued in a straight, or nearly straight, line to Meiringen; but the influx of a large glacier stream from the north-east must have so diverted that of the Aar, that the resultant flow would have been across the lower valley, and almost along the steep face of Kirchet instead of directly across it. This would have been the case, because the glacier stream from the north-east was not only equal in size to that of the Aar valley, but had a more rapid descent, and, therefore, a quicker flow. In the last five miles the Aar valley has a fall of about 1500 feet, while the two north-eastern valleys have an average fall of about 2000 feet; and they are also much wider, which would still further facilitate rapidity of outflow."

Dr. C. M. Aikman gives in the Contemporary an account of the inoculation of agricultural land with pure cultures of bacteria, in the form of Nitragin, for the purpose of promoting plantgrowth. A note on this advance in the science of agriculture will be found on page 326. To the same review Mr. Andrew Lang contributes a budget of records of the rite of "Passing through the Fire," beginning with the earliest accounts of this or some analogous ceremony, and concluding with the most recent authenticated contemporary examples. The rite is very widely diffused, and there is a considerable amount of evidence that the fire-walking is actually practised without apparent injury. In a few villages in Turkey, on the Bulgarian frontier, a festival is held in May, and certain persons still go through the performance of treading and dancing on the red-hot embers of a pile of wood, apparently without sustaining injury. $\mathrm{Mr}$. Lang appeals to men of science to take up the subject, both on account of the widely-diffused religious character of the ceremony, and in order to discover how, granting the facts, the feat is performed. A scientific observer who would go to Bulgaria on May 2I next year, and thoroughly investigate the rite there, noting the state of the fire, the condition of the feet of the ministrants before and after the performance, and photographing the scene, would obtain some definite and valuable information.

A brief mention must suffice for the remaining articles on scientific topics in the magazines received by us. The second part of an historical study, by Mr. J. F. Hewitt, entitled "How the first Priests, the long-haired Shamans, and their successors, the tonsured Barber-surgeons, measured Time," appears in the Westminster Review. The article contains many facts of interest as to the origin of the year in the northern and southern hemispheres. The Century publishes some glimpses of life in Africa, from the journals of the late Mr. E. J. Glave, who completed his remarkable journey across Africa from east to west in May 1895, and died while waiting for the departure of the homeward steamer. The Strand Magazine has a detailed account of the balloon, accessories, and plan of Mr. Andrée, for his aërial polar expedition. There is also a liberally illustrated account of the methods and results of Röntgen photography, by Mr. Alfred W. Porter, in the same magazine. An instructive article on "Atmospheric Pressure" is contributed to Longman's Magazme by Mr. H. Harries. Articles of a like character appear in Chambers's Journal on "The Glastonbury Lake-Dwellers," and "Work in Compressed Air."

NO. I 397 , VOL. 54] 